\title{
ПРАВОВА ОСНОВА РЕАЛІЗАЦІї МЕТОДИКИ «ЗЕЛЕНА КIMHАТА»
}

\begin{abstract}
ЗЕЛЕНСЬКИЙ Свген Сергійович - старший викладач кафедри тактикоспеціальної підготовки Дніпропетровського державного університету внутрішніх справ
\end{abstract}

DOI:10.32782/EP.2020.2.7

УДК 342.95

Мета написання наукової статті - дослідити правову основу реалізацій методики «Зелена кімната» в Украӥні та запропонувати шляхи вирішення проблеми нормативного врегулювання ї̈ застосування правоохоронними органами.

Міжнародні стандарти, які запроваджуються в Україні, чітко визначають, що: а) проведення опитувань дитини має відбуватися без необгрунтованої затримки, відразу після повідомлення фактів компетентним органам; b) проведення опитувань дитини, якщо ще необхідно, має відбуватися у спеціально обладнаному та прилаштованому для изих изілей приміщенні; с) проведення опитувань дитини має проводитися особою, спеціально підготовленою для изих изілей; d) проведення всіх опитувань дитини має проводитися одними й тими самими особами, якщо це можливо та де ие доцільно; е) необхідно забезпечити якомога мениу кількість опитувань $і$ настільки, наскільки ие є вкрай необхідним для ияілей кримінального провадження; f) необхідно забезпечити можливість супроводження дитини ї законним представником або, де це доцільно, дорослим, якого вона сама вибирає, якщо стосовно иієї особи не буде винесено мотивованого рішення про інше.

Крім того, державні органи мають вжити необхіднх законодавчих або інших заходів для забезпечення можливості запису на відеоплівку опитування жертви або, де цуе доцільно, свідка дитини та прийняття таких відеосвідчень як доказу в суді згідно з нормами ї законодавства. Наведене характеризуе основні засади методики «Зелена кімната», яка на законодавчому, загальнообов'язковому рівні съогодні не запроваджена в Украйні.

Автор акцентує увагу на відсутності нормативно-правового акту, який би регламентував застосування методики «Зелена кімната» в Україні. Запропоновано розробити та прийняти Наказ МВС Украӥни «Про затвердження Інструкий шодо застосування методики «Зелена кімната» у роботі Начіональної поліиї Украӥни».

На наш погляд, запропонована Інструкиія має містити вісім розділів: Загальні положення; Основні приниипи застосування методики «Зелена кімната»; Основні напрямки застосування методики «Зелена кімната»; Організаизі роботи полічейсъких під час застосування методики «Зелена кімната»; Загальні умови проведення опитування за методикою «Зелена кімната»; Етапи проведення опитування за методикою «Зелена кімната»; Використання результатів опитування за методикою «Зелена кімната»; Обормлення результатів опитування за методикою «Зелена кімната».

Ключові слова: методика, Зелена кімната, дитина, полічія, наказ, інструкиія.

\section{Актуальність теми}

В умовах запровадження державної політики правосуддя, дружнього до дитини, в Україні, а також зосередження зусиль керівництва Управління ювенальної превенції Національної поліції України на створенні умов світового рівня для проведення допиту дітей, що стали свідками та/ 


\section{Адміністративне право}

або жертвами насильства, а також вчинили насильство, питання правової регламентації запровадження методики «Зелена кімната» в повсякденній діяльності підрозділів Національної поліції стає все більш актуальним.

\section{Постановка проблеми}

Міжнародні стандарти, які запроваджуються в Україні, чітко визначають, що: а) проведення опитувань дитини має відбуватися без необгрунтованої затримки, відразу після повідомлення фактів компетентним органам; b) проведення опитувань дитини, якщо це необхідно, має відбуватися у спеціально обладнаному та прилаштованому для цих цілей приміщенні; с) проведення опитувань дитини має проводитися особою, спеціально підготовленою для цих цілей; d) проведення всіх опитувань дитини має проводитися одними й тими самими особами, якщо це можливо та де це доцільно; е) необхідно забезпечити якомога меншу кількість опитувань і настільки, наскільки це є вкрай необхідним для цілей кримінального провадження; f) необхідно забезпечити можливість супроводження дитини їі законним представником або, де це доцільно, дорослим, якого вона сама вибирає, якщо стосовно цієї особи не буде винесено мотивованого рішення про інше [4]. Крім того, державні органи мають вжити необхідних законодавчих або інших заходів для забезпечення можливості запису на відеоплівку опитування жертви або, де це доцільно, свідка дитини та прийняття таких відеосвідчень, як доказу в суді згідно 3 нормами іiі законодавства [4]. Наведене якраз і характеризує основні засади методики «Зелена кімната», яка на законодавчому, загальнообов'язковому рівні сьогодні не запроваджена в Україні.

Дотримання належних умов під час допиту дитини - це запорука забезпечення прав та свобод дитини, а також запорука ефективного та оперативного проведення розслідування у справі.

У практичних підрозділах Національної поліції, на жаль, дотепер часто формально ставляться до дотримання умов, у яких слід допитувати дитину, через відсут- ність спеціально обладнаних приміщень у кожному територіальному підрозділі Національної поліції. Зазвичай допит дитини відбувається у робочих кабінетах поліцейських, що є недопустимим.

\section{Стан дослідження проблеми}

Допит дитини у кримінальному провадженні був предметом дослідження таких учених, як І. Басистої, В. Васильєва, С. Ефимовича, В. Коновалової, С. Аук'янова, Т. Матюшкової, С. Пришляка, E Стрельцова, С. Тетюєва та інших. Проте питанню правової регламентації запровадження методики «Зелена кімната» в адміністративно-правовій науці не приділено достатньо уваги.

Мета написання наукової статті - дослідити правову основу реалізації методики «Зелена кімната» в України та запропонувати шляхи вирішення проблеми нормативного врегулювання пї застосування правоохоронними органами.

\section{Виклад основного матеріалу}

Методика опитування дітей «Зелена кімната» не $є$ новою для України. Після ратифікації Україною у 2012 році Конвенції Ради Европи про захист дітей від сексуальної експлуатації та сексуального насильства від 25.10.2007, яка встановлюе основні засади опитування дитини [4], МВС України був вироблений, прийнятий та запроваджений наказ «Про затвердження Інструкції з організації роботи підрозділів кримінальної міліції у справах дітей» від 19.12.2012 № 1176 [2]. Даний наказ вперше запровадив поняття «Зелена кімната», визначаючи його зміст та особливості застосування.

Так, методика «Зелена кімната» - це методика проведення інтерв’ювання дитини, яка потерпіла або стала свідком злочину, в умовах, що мінімізують та не допускають повторної травматизації психіки дитини, 3 урахуванням іiі індивідуально-психологічних та психофізіологічних властивостей [2].

Отже, наказ МВС України «Про затвердження Інструкції 3 організації роботи 
підрозділів кримінальної міліції у справах дітей» від 19.12.2012 № 1176, що втратив чинність у 2017 році, нормативно закріплював визначення методики «Зелена кімната» [2], а також порядок їі застосування (розділ VIII Інструкції [2]), а так звані «Зелені кімнати» (відповідні облаштовані приміщення для опитування дитини) були у кожному підрозділі міліції.

Проте через невідповідність світовим стандартам такі «Зелені кімнати» були ліквідовані, а нові одразу створені не були, а вказаний наказ МВС України втратив чинність. Відповідно офіційне застосування методики «Зелена кімната» було призупинено. Це говорить про недотримання принципів правосуддя дружнього до дитини, а також недотримання взятих Україною зобов'язань під час опитування дітей в Україні.

Сьогодні в Україні починають створювати належним чином облаштовані «Зелені кімнати», які відповідають усім міжнародним стандартам, а механізм їх функціонування запущений [5]. Такі кроки влади є необхідними для дотримання прав і свобод дитини під час кримінального провадження, для дотримання міжнародних стандартів у діяльності державних органів України, а також для ефективного здійснення кримінального провадження. Проте поки кількість таки «Зелених кімнат» не є достатньою для того, щоб використовувати їх у всіх випадках, які цього потребують.

Нагальною проблемою вважаємо відсутність правової основи функціонування «Зелених кімнат» та обов'язковості їх застосування у кримінальному провадженні за участю дитини. Так, у змісті наказу МВС України від 19.12.2017 № 1044 «Про затвердження Інструкції з організації роботи підрозділів ювенальної превенції Національної поліції України» не можна зустріти згадку про методику «Зелена кімната» [3]. Проте, як зазначалося, фактично спроби їі запровадження на практиці відбуваються постійно.

За основу при цьому зазвичай беруться методичні рекомендації, розроблені спільним зусиллями Ради Европи, Міжнародного жіночого правозахисного центру «入а Страда-Україна», Українського фонду «Благополуччя дітей» [1], проте які, як відомо, не мають обов'язкового характеру.

3 огляду на викладене, нагальною потребою вважаємо вироблення та прийняття відомчого нормативно-правового акту, який би встановлював загальні засади застосування методики «Зелена кімната».

Ми пропонуємо прийняти Наказ МВС України «Про затвердження Інструкції щодо застосування методики «Зелена кімната» у роботі Національної поліції України». Така Інструкція має закріпити хоча 6 на відомчому рівні визначення поняття «методика «Зелена кімната», інших суміжних понять, а також містити положення щодо реалізації цієї методики. Зауважимо, що запропонована нами Інструкція має врегулювати діяльність саме поліцейських, а не фахівців інших галузей, наприклад, педагога або психолога, діяльність яких регламентована нормативно-правовими актами інших сфер, а також які володіють спеціальними знаннями, прийомами, способами спілкування 3 дитиною, що забезпечать дотримання інтересів дитини під час опитування.

На наш погляд, запропонована Інструкція має містити вісім розділів: Загальні положення; Основні принципи застосування методики «Зелена кімната»; Основні напрямки застосування методики «Зелена кімната»; Організація роботи поліцейських під час застосування методики «Зелена кімната»; Загальні умови проведення опитування за методикою «Зелена кімната»; Етапи проведення опитування за методикою «Зелена кімната»; Використання результатів опитування за методикою «Зелена кімната»; Оформлення результатів опитування за методикою «Зелена кімната».

Розглянемо кожен із них детальніше. Кожен із запропонованих розділів Інструкції розкриває частину процесу застосування методики «Зелена кімната» поліцейськими, що у своїй сукупності становить цілісну процедуру опитування дитини.

Загальні положення запропонованої Інструкції, на наш погляд, мають містити визначення таких понять, як «методика 


\section{Адміністративне право}

«Зелена кімната», «суб'єкти застосування методики «Зелена кімната», «об'єкти застосування методики «Зелена кімната», "дитина», «опитування дитини», «правосуддя, дружне до дитини», "дитина у конфлікті 3 законом», «дитина у контакті з законом». Також у даному розділі пропонуємо дати загальне уявлення про вказану методику та іï значення для кримінального провадження.

Так, головною метою створення і функціонування «Зеленої кімнати» для дітей є соціальний і правовий захист дітей, виявлення та документування злочинної діяльності, спрямованої на дітей чи за участю дітей. «Зелена кімната» може також використовуватися для проведення заходів щодо психологічної профілактики та корекції відхилень у поведінці дітей, виявлення та усунення причин і умов, що сприяють учиненню дітьми злочинів і правопорушень.

Основними принципами застосування методики «Зелена кімната» вважаємо: верховенство права, законність, участь, захищеність, забезпечення найкращих інтересів дитини, захист від дискримінації. Саме їх сутність і пропонуємо розкрити у другому розділі Інструкції.

Основними напрямки застосування методики «Зелена кімната» є: 1. Збір доказового матеріалу про злочин чи правопорушення, в яких дитина стала жертвою чи свідком злочину або правопорушником; 2. Робота з адаптації дитини після скоєння над нею насильства; 3. Поновлення психоемоційного статусу дитини, яка перебуває в стресовому стані внаслідок конфліктної, аварійної чи іншої екстремальної ситуації; 4. Блокування гострих стресових реакцій у дитини; 5. Попередження психоемоційного навантаження у дитини, пом'якшення впливу психотравмуючих ситуацій та психофізичних навантажень; 6. Усунення фізичного дискомфорту та емоційної напруги, нормалізація процесу життєдіяльності; 7. Короткотермінова чи довготермінова психокорекція; 8. Психологічна допомога особам, схильним до різних видів залежностей; 9. Психологічні консультування 3 рекорегування взаємовідносин у родині, навчальних закладах, у дитячому колек- тиві; 10. Попередження, профілактика, корекція негативних наслідків відхилення в поведінці та психологічної деформації дітей, схильних до скоєння правопорушень і злочинів; 11. Допомога дитині зрозуміти й усвідомити причини її поганого пристосування до реальності і надання допомоги в адаптації та побудові більш реалістичної комунікації [1, с. 25].

Організація роботи поліцейських під час застосування методики «Зелена кімната» передбачає відбір поліцейських, які володіють методикою «Зелених кімнатах», постійно працюють 3 дітьми (поліцейські ювенальної превенції, спеціалізація слідчих), а також визначення напрямків та методів комунікації із фахівцями інших галузей (відпрацьований механізм запрошення на допит психологів та педагогів 6 запорукою ефективного та оперативного опитування дитини).

До загальних умов проведення опитування за методикою «Зелена кімната» належить: визначення категорій дітей, 3 якими працюють у «Зелених кімнатах»; категорії дітей, які не можуть перебувати в «Зелених кімнатах»; вимоги до приміщень, у яких проводиться опитування; загальні правила та особливості проведення опитування дитини.

Як правило, «Зелена кімната» для дітей - це два суміжні приміщення: 1) терапевтичний зал, у якому безпосередньо 3 дитиною працюють поліцейський, психолог, залучені фахівці із педіатрії, дитячої гінекології, психіатрії, педагогіки тощо; 2) робоче приміщення для поліцейських ювенальної превенції, слідчого та залучених спеціалістів, 3 якого ведеться спостереження за поведінкою дітей (кімната для спостереження) [1, с. 27].

Етапи проведення опитування за методикою «Зелена кімната». У даному розділі Інструкції пропонуємо провести розподіл запланованої процесуальної дії на етапи, кожний 3 яких виконуе певну функцію. Виокремлюють такі фази опитування: попередня фаза, вступна фаза, фаза вільної розповіді, фаза детальних запитань, заключна фаза [1, с. 83]. Саме розкриття цих фаз і становить зміст вказаного підрозділу. 
Використання результатів опитування за методикою «Зелена кімната». Законні представники дитини, яку опитують у «Зеленій кімнаті», має право ознайомитися 3 результатами проведеного опитування. Інформація, яка отримана в результаті опитування, є доказом у кримінальному провадженні, може бути використана в судовому засіданні, запобігає повторному опитуванню дитини в подальшому у даній справі з метою іï меншої травматизації.

Оформлення результатів опитування за методикою «Зелена кімната» відбувається за допомогою одного з таких методів документування процесу опитування дітей: нотування; фіксування опитування за допомогою аудіоносіїв; фіксування опитування з використанням відеокамери; комбінування вищеперелічених технік [1, с. 97].

Незалежно від застосованого методу, документування процесу опитування має містити інформацію на тему: місця, в якому проводилась процесуальна дія; дати і часу проведення, 3 урахуванням години початку й завершення опитування та перерв; осіб, які брали участь у проведенні опитування; можливих особливих обставин, які мали місце під час опитування; стану фізичного розвитку й вигляду дитини. До документації повинні бути долучені також письмові матеріали та малюнки, виконані дитиною під час опитування [1, с. 97].

Безпосередньо фіксація процесуальної дії опитування дитини фіксується в протоколі опитування дитини, який має правдиво та детально відображати хід процесуальної дії. Вони повинні фіксувати як висловлювання дитини, так і невербальну комунікацію (зміни пози, симптоми рухової тривоги, вегетативні реакції: почервоніння обличчя, тремтіння рук тощо). Документування невербальних реакцій у ході опитування допомагає помітити зміни в поведінці та емоціях дитини залежно від змісту розмови, що, у свою чергу, є важливим елементом при оцінці всього матеріалу [1, с. 98].

\section{Висновки}

Підсумовуючи вище викладене, ми запропонували з метою ефективного застосування методики «Зелена кімната» прийня- ти наказ МВС України «Про затвердження Інструкції щодо застосування методики «Зелена кімната» у роботі Національної поліції України». На наш погляд, така Інструкція має містити 8 розділів, які б комплексно встановлювали на відомчому рівні основні положення проведення опитування дитини за методикою «Зелена кімната», яка 6 стала обов'язковою в застосуванні у визначених Інструкцією випадках. Такий наказ забезпечить реалізацію міжнародних стандартів опитування дитини в Україні, а також створить умови для ефективної роботи поліцейських у рамках кримінального провадження.

\section{Література}

1. Методичні рекомендації щодо опитування дітей, що стали свідками та/або жертвами насильства, а також вчинили насильство: Метод. посіб. / Автори-упоряд.: Д. Пурас, О. Калашник, О. Кочемировська; Т. Цюман; за заг. ред. Т. Цюман. К.: ФОП КЛИМЕНКО, 2015. - 114 с.

2. Про затвердження Інструкції з організації роботи підрозділів кримінальної міліції у справах дітей: Наказ МВС України від 19.12.2012 № 1176 (втратив чинність) [Електронний ресурс]. - Режим доступу: https://zakon.rada.gov.ua/laws/show/z0121-13

3. Про затвердження Інструкції з організації роботи підрозділів ювенальної превенції Національної поліції України: Наказ МВС України від 19.12.2017 № 1044 [Електронний ресурс]. - Режим доступу: https://zakon.rada. gov.ua/laws/show/z0686-18?find $=1$ \&text $=\% \mathrm{D} 0$ $\%$ B7\%D0\%B5\%D0\%BB\%D0\%B5\%D0\%BD

4. Конвенція Ради Европи про захист дітей від сексуальної експлуатації та сексуального насильства від 25.10.2007, Конвенцію ратифіковано з заявами Законом України № 4988-VI від 20.06.2012 [Електронний ресурс]. - Режим доступу: https:// zakon.rada.gov.ua/laws/show/1994_927

5. На Дніпропетровщині почали працювати «кризові кімнати» для дітей, які стали жертвами або свідками злочину [Електронний ресурс]. - Режим доступу: https:// d 1.dp.ua/na-dnipropetrovshhyni-pochalypratsyuvaty-kryzovi-kimnaty-dlya-ditej-yakistaly-zhertvoyu-abo-svidkom-zlochynu 


\section{Адміністративне право}

The purpose of writing a scientific article is to study the legal basis for the implementation of the "Green Room" methodology in Ukraine and to suggest ways to solve the problem of legal settlement of its use by law enforcement agencies.

In accordance with international standards Ukraine shall take the necessary legislative or other measures to ensure that: a) interviews with the child take place without unjustified delay after the facts have been reported to the competent authorities; b) interviews with the child take place, where necessary, in premises designed or adapted for this purpose; c) interviews with the child are carried out by professionals trained for this purpose; d) the same persons, if possible and where appropriate, conduct all interviews with the child; e) the number of interviews is as limited as possible and in so far as strictly necessary for the purpose of criminal proceedings; f) the child may be accompanied by his or her legal representative or, where appropriate, an adult of his or her choice, unless a reasoned decision has been made to the contrary in respect of that person.

Ukraine shall take the necessary legislative or other measures to ensure that all interviews with the victim or, where appropriate, those with a child witness, may be videotaped and that these videotaped interviews may be accepted as evidence during the court proceedings, according to the rules provided by its internal law.

This is exactly what characterizes the basic principles of the "Green Room" method, which is not currently introduced in Ukraine at the legislative, mandatory level.

The author emphasizes the absence of a legal act that would regulate the use of the "Green Room" in Ukraine. It is proposed to develop and adopt the Order of the Ministry of Internal Affairs of Ukraine "On approval of the Instruction on the application of the Green Room methodology in the National Police of Ukraine".

In our opinion, the proposed Instruction should contain eight sections: General provisions; Basic principles of application of the method "Green Room"; The main areas of application of the method "Green Room"; Organization of police work during the application of the "Green Room" method; General conditions of the survey according to the method of "Green Room"; Stages of the survey according to the method of "Green Room"; Using the results of the survey by the method of "Green Room"; Registration of survey results by the method of "Green Room".

Key words: methodology, Green room, child, police, order, instruction. 